
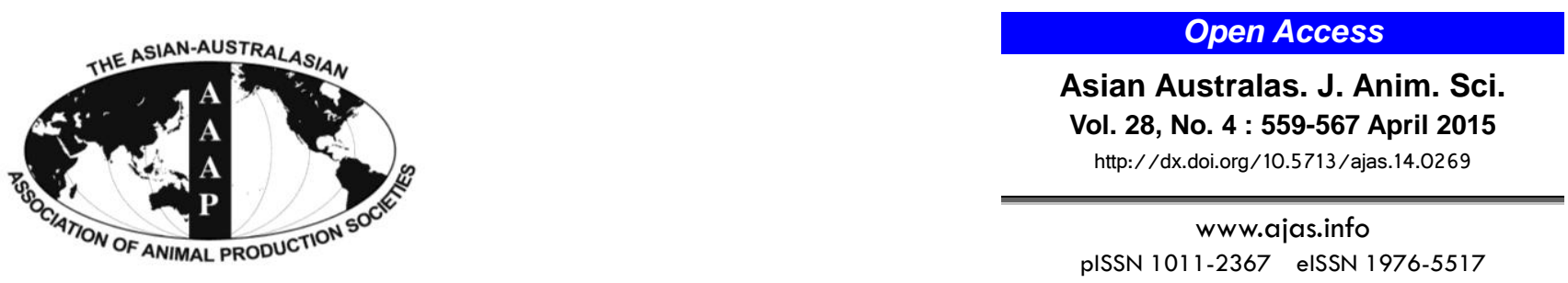

\title{
Ex vivo Digestion of Milk from Red Chittagong Cattle Focusing Proteolysis and Lipolysis
}

\author{
Mohammad Ashiqul Islam*, Dag Ekeberg, Elling-Olav Rukke, and Gerd Elisabeth Vegarud \\ Department of Chemistry, Biotechnology and Food Science, Norwegian University of Life Sciences, \\ NO-1432 Aas, Norway
}

\begin{abstract}
Ex vivo digestion of proteins and fat in Red Chittagong Cattle milk from Bangladesh was carried out using human gastrointestinal enzymes. This was done to investigate the protein digestion in this bovine breed's milk with an especial focus on the degradation of the allergenic milk proteins; $\alpha_{s 1}$-casein and $\beta$-lactoglobulin and also to record the generation of peptides. Lipolysis of the milk fat and release of fatty acids were also under consideration. After $40 \mathrm{~min}$ of gastric digestion, all the $\alpha_{\mathrm{s}}$-caseins were digested completely while $\beta$-lactoglobulin remained intact. During $120 \mathrm{~min}$ of duodenal digestion $\beta$-lactoglobulin was reduced, however, still some intact $\beta$-lactoglobulin was observed. The highest number of peptides was identified from $\beta$-casein and almost all the peptides from $\kappa$-casein and $\beta$-lactoglobulin were identified from the gastric and duodenal samples, respectively. No lipolysis was observed in the gastric phase of digestion. After 120 min of duodenal digestion, milk fat showed 48\% lipolysis. Medium (C10:0 to C16:0) and long $(\geq \mathrm{C} 17: 0)$ chain fatty acids showed $6 \%$ to $19 \%$ less lipolysis than the short (C6:0 to C8:0) chain fatty acids. Among the unsaturated fatty acids $\mathrm{C} 18: 1 \Sigma$ others showed highest lipolysis $(81 \%)$ which was more than three times of C18:2 $\mathrm{Eall}$ and all other unsaturated fatty acids showed lipolysis ranging from $32 \%$ to $38 \%$. The overall digestion of Bangladeshi Red Cattle milk was more or less similar to the digestion of Nordic bovine milk (Norwegian Red Cattle). (Key Words: Gastric Digestion, Duodenal Digestion, $\alpha_{\mathrm{s} 1}-\mathrm{Casein}, \beta-$ Lactoglobulin, Peptide, Fatty Acid)
\end{abstract}

\section{INTRODUCTION}

The use of ex vivo digestion model is important for understanding the mechanisms involved in food digestion and to mimic the human digestion. There are some other purposes as well for using such models are - e.g. investigation of bioactive components, study the survivability of drugs through the gastrointestinal (GI) tract, investigation of the digestibility of food allergens, to design food-based delivery system in the GI tract and to study the structural changes of ingested components.

The most challenging physiological parameters are the individual variation in enzymes, acid and bile salt secretion, substrate availability and retention time in the gastric and intestine. The commercial enzyme(s) preparations are

\footnotetext{
* Corresponding Author: Mohammad Ashiqul Islam. Tel: +47-649 65900, Fax: +47-64965901, E-mail: dairyislambau@gmail.com Submitted Apr. 11, 2014; Revised Jul. 12, 2014; Accepted Sept. 4, 2014
}

purified from different animal species. Generally, the same enzymes purified from different animal species are likely to vary in specificity, functional enzymatic parameters and stability (Furlund et al., 2013). But, to date, most of the in vitro studies regarding protein degradation and peptide generation have been done by using the commercial proteases, mainly of porcine or bovine origin. Whereas, human GI juices are a complex mixture of enzymes, with their isoforms and inhibitors, and bile salts. The sample characteristics, enzyme activity, ionic composition, used mechanical stresses and the digestion duration profoundly affect the results of in vitro digestion (Hur et al., 2011) and simulation of in vivo condition will never be complete. However, making the compromise between accuracy and ease of utilization, in vitro model digestion could be used as a rapid screening tool for foods with different composition and structures (Hur et al., 2011). Few suggest the use of single enzymes in in vitro model digestion but the use of a mixture of enzymes is more realistic and some workers

Copyright $@ 2015$ by Asian-Australasian Journal of Animal Sciences This is an open-access article distributed under the terms of the Creative Commons Attribution Non-Commercial License (http://creativecommons.org/licenses/by-nc/3.0/), which permits unrestricted non-commercial use, distribution, and reproduction in any medium, provided the original work is properly cited. 
prefer to use human digestive juices.

Milk protein digestion and peptides from in vitro digested milk has been studied by several authors (Almaas et al., 2006; Inglingstad et al., 2010; Almaas et al., 2011; Furlund et al., 2013; Devle et al., 2014; Tidona et al., 2014; Islam et al., 2014b). But still more knowledge is needed because of high variability in milk composition between breeds (Miranda et al., 2004; Abd El-Salam and El-Shibiny 2011; Medhammar et al., 2012; Islam et al., 2014a) and in in vitro digestion protocol used (Hur et al., 2011; KopfBolanz et al., 2012; Furlund et al., 2013; Islam et al., 2014b). The structure of milk and milk protein composition may have an influence on its digestibility (Almaas et al., 2006). Tidona et al. (2014) found more rapid degradation of $\beta$-lactoglobulin ( $\beta$ - $\mathrm{Lg}$ )-I when $\beta$-Lg-II is absent in donkey's milk. The heterogeneity in the amino acid composition of milk may result in variation in peptide formation and content after proteolysis (Ulleberg, 2011). The rapid degradation pattern of allergenic milk proteins, $\beta-\mathrm{Lg}$ and $\alpha_{\mathrm{s} 1}$-casein, in Bangladeshi buffalo milk (Islam et al., 2014; unpublished data) also increased interest in checking other bovine milk from Bangladesh. In a previous study, Islam et al. (2014a) concluded that buffalo and Red Chittagong Cattle (RCC) milk showed the highest compositional characteristics for nutritional and technological properties. The dairy potentialities, disease resistance, tolerance to harsh environmental conditions along with low input supply makes the RCC a potential interesting dairy genetic resource. Accordingly, several studies have been conducted regarding the management of the $\mathrm{RCC}$, its productive and reproductive performances, phenotypes and genotypes and recently on principal milk components but studies have yet to test the nutritional quality of the milk.

Very few studies have been conducted regarding the milk lipid digestion and according to Miled et al. (2000), in general, few studies have been reported on lipid digestion. Lipid digestion is more complex than protein digestion regarding the enzymes and physiological conditions in the gut. Factors like food matrix and buffering capacity, emulsion type (oil based/water based), individual secretion of both lipolytic enzymes and bile salts affect the hydrolysis of dietary lipids. The digestion of one nutrient may affect the digestion of others. Devle et al. (2014) and Islam et al. (2014; unpublished data) showed different effects of milk lipids on the protein digestion in cow (Norwegian Red
Cattle) and in buffalo milk, respectively. The objective of the present study was to investigate the digestion of milk from RCC using human gastrointestinal enzymes with a special focus on lipolysis, and proteolysis of the allergenic proteins, $\alpha_{\mathrm{s} 1}$-casein and $\beta$-lactoglobulin.

\section{MATERIALS AND METHODS}

\section{Milk sample}

Mixed whole milk from nineteen RCC cows was collected from Bangladesh Livestock Research Institute dairy farm. Sampling was done from the morning milk. The animals were at different parity number and stage of lactation and the individual milk production during the sampling time varied between 1.3 to $5.0 \mathrm{~L}$. The management (especially feeding) of the animals under sampling was described by Islam et al. (2014a). The samples were preserved by bronopol (1 tablet/40 mL milk; $\mathrm{D} \& \mathrm{~F}$ control systems, Inc. Boston, MA, USA) with minimum delay after the cows were milked. All the milk samples were kept at $-20^{\circ} \mathrm{C}$ and transferred to the Norwegian University of Life Sciences and stored at $-20^{\circ} \mathrm{C}$ until used. Detailed composition of RCC milk including milk protein and fatty acid composition was reported by Islam et al. (2014a) and according to them the true protein and fat content of the RCC milk used herein were 38 and 42 $\mathrm{g} / \mathrm{kg}$ milk, respectively.

\section{Gastrointestinal enzymes}

Human GI enzymes as human gastric juices and human duodenal juices were collected and prepared according to the method of Ulleberg et al. (2011). In brief, aspiration of juices was done on six healthy, fasted (for at least $8 \mathrm{hrs}$ ), adult (20 to 37 years old) volunteers at Lovisenberg Diakonale Hospital, Oslo, Norway. A triple lumen tube (Maxters catheters, Marceille, France) was used for this purpose. The protocol used was approved by the Norwegian Ethical Committee.

\section{Ex vivo digestion}

A two phase digestion, gastric and duodenal digestion was carried out according to the method described by Devle et al. (2014) and Islam et al. (2014b). The details of the ex vivo digestion model are given in Table 1 . The digestion was carried out at $37^{\circ} \mathrm{C}$ in a water bath for different period

Table 1. Details on the ex vivo digestion model

\begin{tabular}{lllccl}
\hline Sample (1 mL milk) & Steps & $\mathrm{pH}$ & Duration $(\mathrm{min})$ & $\mathrm{pH}$ adjusted by & \multicolumn{1}{c}{ Added enzymes and others } \\
\hline Gastric (G) phase & $\mathrm{G} 20$ & 5.0 & 20 & $2 \mathrm{M} \mathrm{HCL}$ & 711 unit pepsin activity/g milk protein. \\
& G40 & 2.5 & 20 & & \\
Duodenal (D) phase & D5 & 7.0 & 5 & $\mathrm{M} \mathrm{NaOH}$ & 558 unit proteolytic activity/g milk protein. \\
& D30 & 7.0 & 30 & & The added duodenal juice also contained \\
& D60 & 7.0 & 60 & 889 unit lipase activity/mL and $2.4 \mathrm{mM} \mathrm{bile}$ \\
& D120 & 7.0 & 120 & salts. \\
\hline
\end{tabular}

All the digestion steps from G40 to D120 were followed by the preceding digestion step(s). 
of time corresponding to the digestion steps (Table 1); then the reaction was stopped by placing them into $-20^{\circ} \mathrm{C}$ (protein samples) or by adding $20 \mathrm{~mL}$ of chloroform and methanol $(2: 1)$ mixture and then placing into $-20^{\circ} \mathrm{C}$ (lipid samples). The digestion experiments were performed in triplicate.

\section{Milk protein degradation profile}

The proteins were separated by sodium dodecyl sulfate polyacrylamide gel electrophoresis (SDS-PAGE) using a modified method described by Islam et al. (2014b). The digested samples were mixed with the sample buffer (1:2) and applied on a precast gel $(6.5$ to $200 \mathrm{kDa}$; mini PROTEAN TGX precast gels, Tris Glycine extended, BioRad laboratories, Inc. Made in United States) and ran for 35 min at $200 \mathrm{~V}$. Then it was fixed, stained with Coomassie Brilliant Blue, destained and kept in preservation solution. Six gels were run.

\section{Protein identification}

A method described by Devle et al. (2014) and Islam et al. (2014b) was used to identify the protein bands in the SDS-PAGE. In brief, the identification of bands of interest was done by nano-ultra performance liquid chromatography (UPLC)/Q-Exactive Mass Spectrometry (MS), both from Thermo Fisher Scientific, Bremen, Germany. The UPLC was equipped with a trap column (Acclaim PepMap100, C18, $5 \mu \mathrm{m}, 100 \AA, 300 \mu \mathrm{m}$ i.d. $\times 5 \mathrm{~mm}$, Thermo Fisher Scientific, Bremen, Germany) and a $50 \quad \mathrm{~cm} \times 75 \mu \mathrm{m}$ analytical column (Acclaim PepMap RSLC C18, $2 \mu \mathrm{m}, 100$ $\AA$ A, $75 \mu \mathrm{m}$ i.d. $\times 50 \mathrm{~cm}$, nanoViper, Bremen, Germany). The Q-Exactive MS was in full scan mode (300 to $1,600 \mathrm{~m} / \mathrm{z}$ ) followed by (up to) $5 \mathrm{MS} 2$ scans at resolution 70.000 and 35000 , respectively and the used neutral collision energy was 28. For MS/MS, $1=\mathrm{z}>5$ (' $\mathrm{z}$ ' is the charge) precursors were excluded. An in-house Mascot (v.2.4) server was used for the database search. The data base was National Center for Biotechnology Information (NCBI), number: 20130131 (22749596 sequences; 7819872540 residues).

\section{Identification of peptides}

Peptides were identified by using the method described by Islam et al. (2014b). A nanoACQUITY UPLC (Waters, Milford, MA, USA) and quadrupole-time-of-flight (Q-TOF) Ultima MS (Micromass Ltd., Manchester, UK) was used for this purpose. The columns in the UPLC were $5-\mu \mathrm{m}$ symmetry C18 trap column $(180 \mu \mathrm{m} \times 20 \mathrm{~mm}$; Waters, USA) and 1.7- $\mu \mathrm{m}$ BEH C18 analytical column $(75 \mu \mathrm{m} \times 100 \mathrm{~mm}$; Waters, USA). Identification of peptides was done in duplicate.

\section{Multiple sequence alignment of the peptides}

The multiple sequence alignment (MSA) was done to identify the minimal overlapped peptides and their position in the protein sequence. A method described by Islam et al. (2014b) was used with modifications. The software used was Clustal omega (version: CLUSTAL O (1.2.1); http://www.ebi.ac.uk/Tools/msa/clustalo/) and Jalview 2.8.0b1.

\section{Lipid analysis}

The total lipid content was first extracted and then separated by solid phase extraction (SPE) into neutral lipid (NL) and free fatty acid (FFA). The fatty acid methyl esters (FAMEs) were identified by gas chromatography-magnetic sector mass spectrometry (GC-MS). A modified method according to Devle et al. (2014) as described by Islam et al. (2014b) was followed in lipid analysis. In brief, total lipid was extracted by $20 \mathrm{~mL}$ of chloroform and methanol mixture (2:1) that was added immediately after the digestion. The SPE was carried-out on a liquid handling robot (Gilson, GX-274 ASPEC, Middleton, WI, USA). Elution of NL and FFA were done with $5 \mathrm{~mL}$ chloroform and diethyl ether:acetic acid (98:2), respectively. The FAMEs of NL and FFA were prepared by using sodiummethanolate and boron trifluride-methanol complex, respectively. In GC (Agilent 6890 series, Agilent Technology, Wilmington, DE, USA), 50 m CP-Sil 88 capillary column with ID 0.25 and $0.20 \mu \mathrm{m}$ thickness (Varian, Middelburgh, The Netherlands) was used. The coupling Autospec Ultima MS was from Micromass Ltd. Manchester, England using electron ionization ion source (mass ranze $m / z$ 40-600). It was done in triplicate.

\section{Statistical analysis}

One way Analysis of Variance was done by using Minitab 17 (Minitab Ltd., Brandon Court, Coventry, UK). In case of significant difference, Tukey's test was employed for mean separation.

\section{RESULTS AND DISCUSSION}

\section{Protein degradation}

The protein degradation pattern during the ex vivo digestion is shown in Figure 1. The majority of the caseins were digested after initial $20 \mathrm{~min}$ of gastric digestion and appeared completely digested after $40 \mathrm{~min}$ of gastric phase.

The whey protein serum albumin was degraded during the gastric digestion for $40 \mathrm{~min}$ while $\beta$-lactoglobulin and some of the $\alpha$-lactalbumin were resistant. After $120 \mathrm{~min}$ of duodenal digestion, some $\beta$-lactoglobulin was found intact (Figure 1: lane D5, band 1) together with the fragments of serum albumin. The other bands, 2, 3 and 4 (lane D5) in Figure 1 were the blend of $\beta$-lactoglobulin, $\alpha$-lactalbumin and serum albumin. In the duodenal digested samples, some bands that appear at approximately 30 to $60 \mathrm{kDa}$ (a, b, c, and $d$ in Figure 1) are the digestive enzymes present in the 


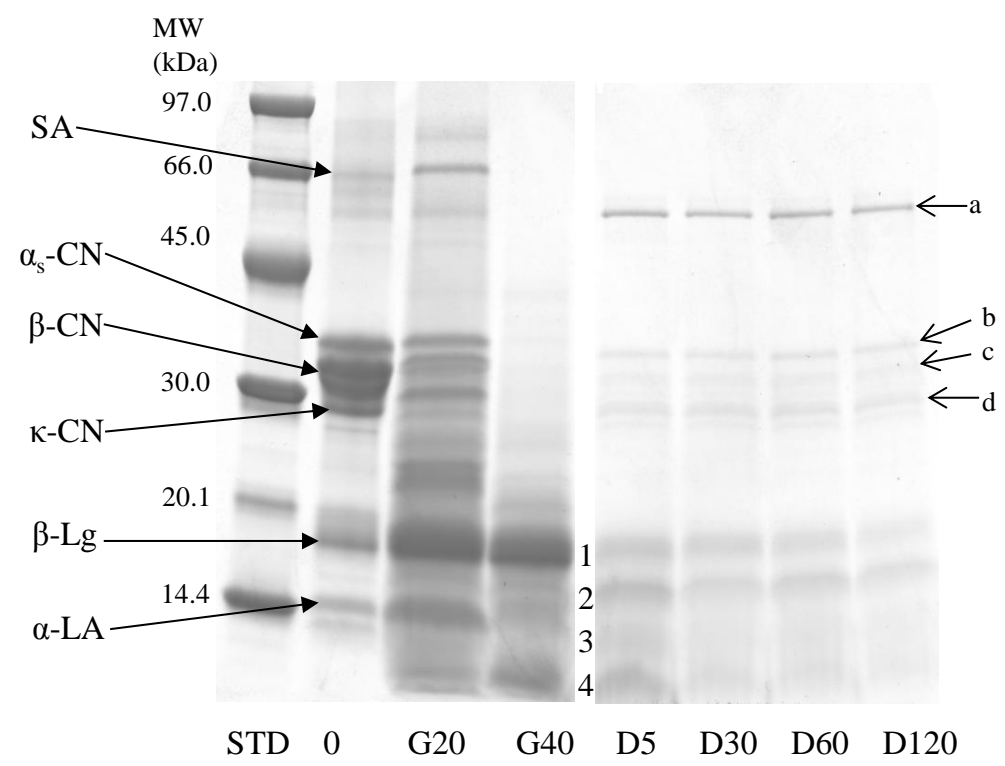

Figure 1. Protein degradation profile of Red Chittagong Cattle milk after ex vivo gastric (G) and duodenal (D) digestion. MW, molecular weight; $\mathrm{kDa}$, kilo dalton; SA, serum albumin; $\mathrm{CN}$, casein; $\beta$-Lg, $\beta$-lactoglobulin; $\alpha$-LA, $\alpha$-lactalbumin; STD, low molecular weight marker; 0, undigested sample; G20, gastric digestion for $20 \mathrm{~min}$ at $\mathrm{pH}$ 5.0; G40, gastric digestion for $20 \mathrm{~min}$ at $\mathrm{pH}$ 2.5; D5, D30, D60 and D120, duodenal digestion for 5, 30, 60, and 120 min, respectively at pH 7.0; D5:1, $\beta$-lactoglobulin and serum albumin; D05:2, 3, and 4, $\beta$-lactoglobulin, $\alpha$-lactalbumin and serum albumin; a, amylase; b, carboxypeptidase, chymotrypsin, elastase, lipase, gastricsin and amylase; c, carboxypeptidase, elastase, lipase, trypsin and amylase; d, elastase, carboxypeptidase, chymotrypsin, amylase, lipase, and trypsin.

duodenal juices (Devle et al., 2014).

In all model digestion studies, the type, amount and activity of the enzymes, as well as $\mathrm{pH}$ used appear to influence the caseins digestion during the gastric phase (Almass et al., 2006). Kopf-Bolanz et al. (2012) reported a complete digestion of all the caseins after $30 \mathrm{~min}$ in vitro gastric digestion, while Gallier et al. (2012) showed a total degradation of caseins after $45 \mathrm{~min}$ using commercial enzymes of animal origin. When human gastrointestinal enzymes were used, Devle et al. (2014) reported a complete casein digestion after $40 \mathrm{~min}$. The results of the present study on bovine milk are in agreement with these results. However, Islam et al. (2014; unpublished data) found traces

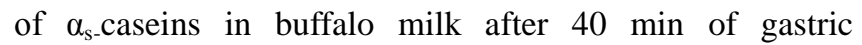
digestion. Tidona et al. (2014) reported a very low degradation of the caseins in donkey's milk after $30 \mathrm{~min}$ of gastric digestion. These two findings indicate the importance of species variation and are in agreement with Inglingstad et al. (2010) in a study on human, equine, goat and bovine milk digestion.

The present study showed some intact $\beta$-lactoglobulin after 120 min of duodenal digestion and this is in line with the report on bovine milk by Devle et al. (2014), Gallier et al. (2012) and Inglingstad et al. (2010). However, KopfBolanz et al. (2012) obtained almost complete digestion of bovine $\beta$-lactoglobulin by commercial gastric (120 min) and pancreatic enzymes (30, 60, 90, and $120 \mathrm{~min}$ ). However, another important result obtained by Islam et al. (2014; unpublished data) showed almost complete hydrolysis of $\beta$ lactoglobulin in full fat buffalo milk after 5 min of duodenal digestion. So, genetic factors for the degradation of $\beta$ lactoglobulin may be of importance as was also reported by Tidona et al. (2014) in donkey milk digestion. Another factor important for the digestion of $\beta$-lactoglobulin seems to be the bile salts; $\geq 2 \mathrm{mM}$ concentration may accelerate the digestion of the $\beta$-lactoglobulin (Gass et al., 2007). The presence of $\alpha$-lactalbumin in band 2, 3, and 4 (D5, Figure 1) confirmed by UPLC-MS, indicate the hydrolysis of $\alpha$ lactalbumin and Kopf-Bolanz et al. (2012) reported the complete digestion of $\alpha$-lactalbumin after $30 \mathrm{~min}$ of duodenal digestion using commercial enzymes.

\section{Peptides}

The total number of identified peptides from the different milk proteins during the different phases of ex vivo

Table 2. Number of peptides identified from Red Chittagong Cattle milk proteins at different stages of ex vivo digestion

\begin{tabular}{lcccc}
\hline Protein & G20 & G40 & D5 & D120 \\
\hline$\alpha_{\mathrm{s} 1}-\mathrm{CN}$ & 15 & 12 & 13 & 02 \\
$\alpha_{\mathrm{s} 2}-\mathrm{CN}$ & 04 & 04 & 07 & 01 \\
$\beta-\mathrm{CN}$ & 36 & 35 & 40 & 31 \\
$\kappa-\mathrm{CN}$ & 10 & 08 & 03 & - \\
$\beta-\mathrm{Lg}$ & 01 & 01 & 03 & 05 \\
\hline
\end{tabular}

G20, Gastric digestion for $20 \mathrm{~min}$ at $\mathrm{pH}$ 5; G40, Gastric digestion for 20 $\mathrm{min}$ at $\mathrm{pH} 2.5$; D5 and D120, Duodenal digestion for 5 and $120 \mathrm{~min}$, respectively at $\mathrm{pH} 7$; $\mathrm{CN}$, Casein; $\mathrm{Lg}$, lactoglobulin. 
Table 3. i) Minimal overlapped gastric and duodenal peptides from different milk proteins of ex vivo digested Red Chittagong Cattle milk

\begin{tabular}{|c|c|c|c|}
\hline EMW (Da) & Position $^{1}$ & Peptide & Rich in .......residues $^{2}$ \\
\hline \multicolumn{4}{|c|}{ Gastric peptides from $\alpha_{\mathrm{s} 1}$-Casein (accession number ${ }^{3}$ : B5B3R8) } \\
\hline 1000.452 & $165-171$ & FRQFYQL & Hydrophobic and side chain containing \\
\hline 1384.794 & $114-124$ & LRLKKYKVPQL & Hydrophobic and basic \\
\hline 1499.726 & $95-106$ & HIQKEDVPSERY & Side chain containing, hydrophobic and acidic \\
\hline 1890.858 & $141-157$ & GIHAQQKEPMIGVNQEL & Hydrophobic and side chain containing \\
\hline 1948.838 & $39-55$ & FVAPFPEVFGKEKVNEL & Hydrophobic \\
\hline 2214.998 & $195-214$ & SDIPNPIGSENSEKTTMPLW & Hydrophobic and side chain containing \\
\hline 2346.169 & $16-35$ & RPKHPIKHQGLPQEVLNENL & Hydrophobic and side chain containing \\
\hline Consensus $^{4}$ & & RPPPIGKEKVPQLNL & Hydrophobic, side chain containing and basic \\
\hline \multicolumn{4}{|c|}{ Duodenal peptides from $\alpha_{\mathrm{s} 1}$-Casein (accession number: B5B3R8) } \\
\hline 1236.623 & $40-50$ & FVAPFPEVFGK & Hydrophobic \\
\hline 1298.677 & $119-129$ & YKVPQLEIVPN & Hydrophobic and side chain containing \\
\hline 1336.628 & $95-105$ & HIQKEDVPSER & Side chain containing, hydrophobic and acidic \\
\hline 1956.862 & $195-213$ & SDIPNPIGSENSGKTTMPL & Side chain containing and hydrophobic \\
\hline 1965.025 & $19-35$ & HPIKHQGLPQEVLNENL & Hydrophobic and side chain containing \\
\hline 2019.977 & $140-157$ & EGIHAQQKEPMIGVNQEL & Hydrophobic and side chain containing \\
\hline Consensus & & IPQPEGVPNEGVEL & Side chain containing, hydrophobic and acidic \\
\hline \multicolumn{4}{|c|}{ Gastric peptides from $\alpha_{\mathrm{s} 2}$-Casein (accession number: P02663) } \\
\hline 1196.68 & 181-189 & KISQRYQKF & Hydrophobic and side chain containing \\
\hline 1221.59 & $58-67$ & VVRNANEEEY & Hydrophobic, side chain containing and acidic \\
\hline 2831.49 & $114-138$ & LYQGPIVLNPWDQVKRNAVPITPTL & Hydrophobic and side chain containing \\
\hline 2924.65 & $111-135$ & LQYLYQGPIVLNPWDQVKRNAVPIT & Hydrophobic and side chain containing \\
\hline Consensus & & LYQGPIVLNPWDQVKRNAVPIT & Hydrophobic and side chain containing \\
\hline \multicolumn{4}{|c|}{ Duodenal peptides from $\alpha_{\mathrm{s} 2}$-Casein (accession number: P02663) } \\
\hline 1245.61 & 85-94 & KITVDDKHYQ & Side chain containing, hydrophobic and acidic \\
\hline 1733.88 & $166-179$ & TKLTEEEKNRLNFL & \\
\hline 1738.81 & $96-109$ & ALNEINQFYQKFPQ & Hydrophobic and side chain containing \\
\hline 2039.03 & $114-130$ & LYQGPIVLNPWDQVKRN & Hydrophobic and side chain containing \\
\hline 2044.98 & $111-127$ & LQYLYQGPIVLNPWDQV & Hydrophobic and side chain containing \\
\hline Consensus & & LYQGPIKLNEWDQVYQNF & Hydrophobic and side chain containing \\
\hline \multicolumn{4}{|c|}{ Gastric peptides from $\beta$-Casein (accession number: P02666) } \\
\hline 1243.66 & $109-120$ & GVSKVKEAMAPK & Hydrophobic and basic \\
\hline 1511.716 & $60-72$ & LQDKIHPFAQTQS & Hydrophobic and side chain containing \\
\hline 1624.78 & $16-29$ & RELEELNVPGEIVE & Hydrophobic and acidic \\
\hline 1873.978 & $143-158$ & TDVENLHLPLPLLQSW & Hydrophobic and side chain containing \\
\hline 2015.03 & $140-157$ & LTLTDVENLHLPLPLLQS & Hydrophobic and side chain containing \\
\hline 2178.17 & $96-115$ & PVVVPPFLQPEVMGVSKVKE & Hydrophobic \\
\hline 2253.22 & $205-224$ & FLLYEQPVLGPVRGPFPIIV & Hydrophobic \\
\hline 2876.36 & $179-204$ & SLSQSKVLPVPQKAVPYPQRDMPIQA & Hydrophobic and side chain containing \\
\hline 2881.476 & $156-180$ & QSWMHQPHQPLPPTVMFPPQSVLSL & Hydrophobic and side chain containing \\
\hline 2901.51 & $129-154$ & PVEPFTESQSLTLTDVENLHLPLPLL & Hydrophobic and side chain containing \\
\hline 3935.19 & $73-108$ & $\begin{array}{l}\text { LVYPFPGPIPNSLPQNIPPLTQTPVVVPPFL } \\
\text { QPEVM }\end{array}$ & Hydrophobic and side chain containing \\
\hline Consensus & & $\begin{array}{l}\text { LLYEQPVPGPIVPLPQKIPQTPVPVPPFLQP } \\
\text { EVLGLTDVENLHLPLPLLQS }\end{array}$ & Hydrophobic and side chain containing \\
\hline
\end{tabular}

EMW, experimental molecular weight.

${ }^{1}$ Position in the whole protein sequence. ${ }^{2}$ Residues properties were obtained from CLUSTAL O (1.2.1).

${ }^{3}$ For the whole protein sequence. ${ }^{4}$ Consensus was generated from Jalview 2.8.0b1.

digestion is shown in Table 2. The minimal overlapped peptides from the different milk proteins after gastric and duodenal phase of digestion with their corresponding position in the protein sequence are given in Table 3 (i and ii). Maximum numbers of peptides were identified from the $\beta$-casein followed by $\alpha_{\mathrm{s} 1}$-casein, $\kappa$-casein, $\alpha_{\mathrm{s} 2}$-casein and $\beta$ lactoglobulin. Most of the peptides from $\kappa$-casein and $\beta$ lactoglobulin were identified from gastric and duodenal 
Table 3. ii) Minimal overlapped gastric and duodenal peptides from different milk proteins of ex vivo digested Red Chittagong Cattle milk (Continued)

\begin{tabular}{|c|c|c|c|}
\hline EMW (Da) & Position $^{1}$ & Peptide & Rich in .......residues $^{2}$ \\
\hline \multicolumn{4}{|c|}{ Duodenal peptides from $\beta$-Casein (accession number ${ }^{3}$ : P02666) } \\
\hline 1470.67 & $56-67$ & TEDELQDKIHPF & Hydrophobic, acidic and side chain containing \\
\hline 1624.78 & $16-29$ & RELEELNVPGEIVE & Hydrophobic and acidic \\
\hline 1887.01 & $139-155$ & SLTLTDVENLHLPLPLL & Hydrophobic and side chain containing \\
\hline 1893.94 & $206-222$ & LLYQEPVLGPVRGPFPI & Hydrophobic and side chain containing \\
\hline 1993.08 & $207-224$ & LYQEPVLGPVRGPFPIIV & Hydrophobic and side chain containing \\
\hline 2004.98 & $143-159$ & TDVENLHLPLPLLQSWM & Hydrophobic and side chain containing \\
\hline 2277.06 & $121-139$ & HKEMPFPKYPVEPFTESQS & Hydrophobic and side chain containing \\
\hline 2681.28 & $156-178$ & QSWMHQPHQPLPPTVMFPPQSVL & Hydrophobic and side chain containing \\
\hline 3935.10 & $73-108$ & $\begin{array}{l}\text { LVYPFPGPIPNSLPQNIPPLTQTPVVVPPFLQ } \\
\text { PEVM }\end{array}$ & Hydrophobic and side chain containing \\
\hline Consensus $^{4}$ & & $\begin{array}{l}\text { LLDQENLHGPVRGPFPILIEMPQPPVEPFLQ } \\
\text { EQS }\end{array}$ & Hydrophobic and side chain containing \\
\hline \multicolumn{4}{|c|}{ Gastric peptides from $\kappa$-Casein (accession number: P02668) } \\
\hline 1796.97 & $39-53$ & FSDKIAKYIPIQYVL & Hydrophobic and side chain containing \\
\hline 1267.59 & $52-60$ & VLSRYPSYGLN & Side chain containing, hydrophobic \\
\hline 1197.58 & $117-126$ & ARHPHPHLSF & Hydrophobic and side chain containing \\
\hline 1108.51 & $63-71$ & YYQQKPVAL & Hydrophobic and side chain containing \\
\hline 1536.84 & $88-100$ & VRSPAQILQWQVL & Hydrophobic and side chain containing \\
\hline 2861.30 & $72-96$ & INNQFLPYPYYAKPAAVRSPAQILQ & Hydrophobic and side chain containing \\
\hline Consensus & & PYKPVAVRSPAQILQ & Hydrophobic and side chain containing \\
\hline \multicolumn{4}{|c|}{ Duodenal peptides from $\beta$-lactoglobulin (accession number: P02754) } \\
\hline 1942.94 & $57-73$ & VYVEELKPTPEGDLEIL & Hydrophobic and acidic \\
\hline 1634.71 & $141-154$ & TPEVDDEALEKFDK & Acidic and hydrophobic \\
\hline 1064.53 & $108-116$ & VLVLDTDYK & Hydrophobic \\
\hline Consensus & & VKTPEDEL & Acidic and hydrophobic \\
\hline
\end{tabular}

EMW, experimental molecular weight.

${ }^{1}$ Position in the whole protein sequence. ${ }^{2}$ Residues properties were obtained from CLUSTAL O (1.2.1).

${ }^{3}$ For the whole protein sequence. ${ }^{4}$ Consensus was generated from Jalview 2.8.0b1.

phase of digestion, respectively (Table 2). This is in agreement with the results obtained on buffalo milk by Islam et al. (2014; unpublished data) and Islam et al. (2014b). The sequence coverage of the identified minimal overlapped peptides (Table 3 , i and ii) corresponded well with the number of total identified peptides (Table 2); $\beta$ casein showed more extensive hydrolysis, next was $\alpha_{\mathrm{s} 1^{-}}$ casein followed by $\kappa$-casein, $\alpha_{\mathrm{s} 2}$-casein and $\beta$-lactoglobulin. The presence of proline in almost all the peptides and the hydrophobicity of all the peptides are notable. These results are also in agreement with the results showed by Islam et al. (2014; unpublished data) and Islam et al. (2014b). Proline is known as a helix breaker in the protein structure and may be the proteolytic enzymes have less access to the hydrophobic sequence for further proteolysis. The extent of hydrolysis of the proteins, especially the caseins (Figure 1) was not evident neither by the number of identified peptides (Table 2) nor by the protein sequence coverage by the minimal overlapped peptides (Table 3, i and ii). This may be explained by the detection limit of the UPLC/Q-TOF MS that can identify peptides with the lowest molecular weight of $0.80 \mathrm{kDa}$. Peptides with lower molecular size as di-, tri-, and tetra-peptides and free amino acids were not detected in this study. According to Kopf-Bolanz et al. (2012) 50\% of the total milk proteins were degraded into di- and tripeptides and $10 \%$ of the proteins were degraded to the free amino acids. They also mentioned that an absence of bile salts may reduce the degradability and concluded that the size distribution of the proteins and peptides in the range of $5 \mathrm{kDa}$ and tripeptides was unclear. However, the digestion conditions used in the present study and those in the study of Kopf-Bolanz et al. (2012) are different.

\section{Lipolysis and generation of free fatty acids during $e x$ vivo digestion}

Milk fat consists of $95 \%$ triacylglycerol (Haug et al., 2007) and more than $95 \%$ of the milk fat can be absorbed (Mu and Hoy, 2004). But before absorption, the fat needs to be digested. The pre-duodenal (lingual and gastric) lipases and duodenal (pancreatic) lipase hydrolyze the triacylglycerol to FFAs and monoacylglycerol. These lipases attack ester bonds at $s n-1$ and $s n-3$ position of the 
triacylglycerol (Rogalska et al., 1990; Carriere et al., 1994; Miled et al., 2000; Armand, 2007). Different reports exist regarding the exact contribution of the pre-duodenal lipases (Carriere et al., 1993; Pafumi et al., 2002; Mu and Hoy, 2004; Gallier et al., 2013) to the total lipolysis of triacylglycerol and according to Jensen (2002) it could be $25 \%$ to $40 \%$ of the triacylglycerol.

The lipolysis of NL of RCC milk fat during the gastric and duodenal ex vivo digestion and subsequent release of FFAs are given in Figure 2. No lipolysis was observed after $40 \mathrm{~min}$ of gastric digestion. This is in agreement with the reported gastric lipolysis of full fat bovine milk, full fat buffalo milk, and $2 \%$ cod liver oil enriched buffalo skimmed milk (Devle et al., 2014; Islam et al., 2014; unpublished data; Islam et al., 2014b). The possible reasons are as mentioned earlier by different authors (Devle et al., 2014; Islam et al., 2014b) - firstly, the optimum $\mathrm{pH}$ for the gastric lipase activity is 5 to 6 (Carriere et al., 1993) and secondly, insufficient secretion of gastric lipases because the volunteers were in a semi-fasting condition and not stimulated for lipid digestion. However, it has been reported that gastric digestion of milk fat is important for further duodenal lipolysis (Jensen 2002; Ye et al., 2011; Gallier et al., 2012). A sharp rise of FFAs (33\%) was shown after 30 min of duodenal digestion. The proportion of FFA after 60 min of duodenal digestion was $15.6 \%$ higher than at $30 \mathrm{~min}$ and the proportion after 60 and 120 min were more or less similar. The sharp increase in FFAs after 30 min duodenal digestion is in line with the results reported by Devle et al. (2014) in cows milk, Islam et al. (2014; unpublished data) in buffalo milk and Islam et al. (2014b) in $2 \%$ cod liver oil fortified buffalo skimmed milk. The bile salts concentration was $2.4 \mathrm{mM}$ in the aspirates used in the present study, whereas, the aspirates used by Devle et al. (2014) had only $1.0 \mathrm{mM}$ bile salts. Moreover, the milk fat globule size of the RCC milk $(3.4 \mu \mathrm{m})$ was smaller than in the buffalo milk $(12.3 \mu \mathrm{m})$ as reported by Islam et al. (2014a). Bile salts are important for accelarating lipolysis by creating small lipid micelles. The present study ended with $48 \%$ lipolysis of the NL after 120 min of duodenal digestion. Final lipolysis after 120 min of duodenal digestion observed in cow and buffalo milk was $40 \%$ and 35\%, respectively (Devle et al., 2014; Islam et al., 2014; unpublished data). In the present study few inconsistent fatty acids (C13:0, C20:0, C17:1 n-7, C18:3 n-3, C20:4 n-6) were also observed and are included in the results presented in Figure 2 but not shown in Table 4. Part of this inconsistency may arise from the phospholipids. However, we did not take phospholipids in consideration as Devle et al. (2014) reported a non-significant digestion of the phospholipids.

The changes in the concentration of FFAs during the different steps of ex vivo digestion are given in Table 4 which also includes the lipolysis (\%) of individual fatty acids. Statistical analysis revealed that the concentration of the fatty acids were significantly $(\mathrm{p} \leq 0.001)$ different in different digestion steps except C17:0. Few of them were highest in D120 step, some were found similar between D30 and D60 steps and few were found similar among D30, D60, and D120 steps. The changes in the FFA concentration stays close to the lipolysis reported in Figure 2 when the standard deviations were taken into consideration. The standard deviation of undigested, G40, D30, D60, and D120

Table 4. Individual fatty acid (FA) concentrations (mean $\pm \mathrm{STD} \mu \mathrm{g} / \mathrm{mL}$ milk) in the free fatty acid fraction of Red Chittagong Cattle milk during digestion with human gastric (G) and duodenal (D) juices, and their lipolysis

\begin{tabular}{|c|c|c|c|c|c|c|}
\hline Fatty acids & G40 & D30 & D60 & D120 & p-value & Lipolysis (\%) \\
\hline C6:0 & $2.4^{\mathrm{D}} \pm 0.7$ & $70.0^{\mathrm{C}} \pm 8.3$ & $82.9^{\mathrm{B}} \pm 3.8$ & $120.8^{\mathrm{A}} \pm 3.8$ & 0.000 & 54.8 \\
\hline C8:0 & $2.2^{\mathrm{C}} \pm 0.8$ & $135.2^{\mathrm{B}} \pm 27.1$ & $191.2^{\mathrm{A}} \pm 14.3$ & $227.9^{\mathrm{A}} \pm 7.3$ & 0.000 & 49.1 \\
\hline C10:0 & $8.8^{\mathrm{D}} \pm 0.7$ & $374.8^{\mathrm{C}} \pm 24.7$ & $449.1^{\mathrm{B}} \pm 26.1$ & $503.2^{\mathrm{A}} \pm 16.9$ & 0.000 & 31.2 \\
\hline C12:0 & $14.8^{\mathrm{C}} \pm 1.4$ & $499.1^{\mathrm{B}} \pm 36.8$ & $578.9^{\mathrm{A}} \pm 38.7$ & $650.7^{\mathrm{A}} \pm 24.7$ & 0.000 & 30.7 \\
\hline C14:0 & $40.5^{\mathrm{D}} \pm 5.3$ & $1,627.0^{\mathrm{C}} \pm 107.0$ & $1,900.2^{\mathrm{B}} \pm 74.1$ & $2143.7^{\mathrm{A}} \pm 55.4$ & 0.000 & 33.0 \\
\hline C15:0 & nd & $278.9^{\mathrm{B}} \pm 28.5$ & $349.6^{\mathrm{A}} \pm 13.3$ & $385.6^{\mathrm{A}} \pm 11.3$ & 0.001 & 35.6 \\
\hline C16:0 & $150.6^{\mathrm{D}} \pm 20.6$ & $5,161.0^{C} \pm 472.0$ & $6,164.0^{\mathrm{B}} \pm 304.0$ & $7,114.0^{\mathrm{A}} \pm 278.0$ & 0.000 & 36.1 \\
\hline C17:0 & nd & $151.0 \pm 20.1$ & $304.2 \pm 176.9$ & $223.4 \pm 10.4$ & 0.267 & 49.2 \\
\hline C18:0 & $84.9^{\mathrm{D}} \pm 7.7$ & $1,786.0^{\mathrm{C}} \pm 218$ & $2,302.1^{\mathrm{B}} \pm 107.3$ & $2,687.8^{\mathrm{A}} \pm 135.2$ & 0.000 & 43.9 \\
\hline$\Sigma$ SFA & $304.1^{\mathrm{D}} \pm 36.7$ & $10,083 \cdot 1^{\mathrm{C}} \pm 927.3$ & $12,321.9^{\mathrm{B}} \pm 396.2$ & $14,057.3^{\mathrm{A}} \pm 506.2$ & 0.000 & 36.6 \\
\hline C10:1 n-6 & $2.2^{\mathrm{C}} \pm 0.2$ & $60.5^{\mathrm{B}} \pm 7.4$ & $80.4^{\mathrm{A}} \pm 7.8$ & $82.5^{\mathrm{A}} \pm 4.2$ & 0.000 & 37.6 \\
\hline C14:1 n-5 & $4.9^{C} \pm 2.6$ & $249.5^{\mathrm{B}} \pm 20.7$ & $308.3^{\mathrm{A}} \pm 15.1$ & $332.0^{\mathrm{A}} \pm 10.1$ & 0.000 & 31.9 \\
\hline C16:1 n-7 & nd & $348.4^{\mathrm{B}} \pm 30.7$ & $443.0^{\mathrm{A}} \pm 21.9$ & $475.6^{\mathrm{A}} \pm 12.0$ & 0.001 & 33.7 \\
\hline C18:1 n-9 & $45.4^{\mathrm{C}} \pm 8.0$ & $3,990.0^{\mathrm{B}} \pm 480.0$ & $5,072.0^{\mathrm{A}} \pm 244.0$ & $5,744.0^{\mathrm{A}} \pm 216.0$ & 0.000 & 32.7 \\
\hline C18:1 Eothers & nd & $103.8^{\mathrm{C}} \pm 4.1$ & $137.0^{\mathrm{B}} \pm 12.4$ & $157.9^{\mathrm{A}} \pm 5.8$ & 0.001 & 80.8 \\
\hline C18:2 इall & nd & $244.1^{\mathrm{B}} \pm 8.9$ & $317.0^{\mathrm{A}} \pm 12.4$ & $323.7^{\mathrm{A}} \pm 9.5$ & 0.000 & 24.4 \\
\hline$\Sigma$ USFA & $52.5^{\mathrm{C}} \pm 10.8$ & $4,996.3^{\mathrm{B}} \pm 546.6$ & $6,357.3^{\mathrm{A}} \pm 307.7$ & $7,115.6^{\mathrm{A}} \pm 251.0$ & 0.000 & 34.3 \\
\hline
\end{tabular}

STD, standard deviation; nd, not detected; SFA, saturated fatty acid; USFA, Unsaturated fatty acid.

Lipolysis (\%) of individual FA in neutral lipid (NL) fraction is also presented herein. 


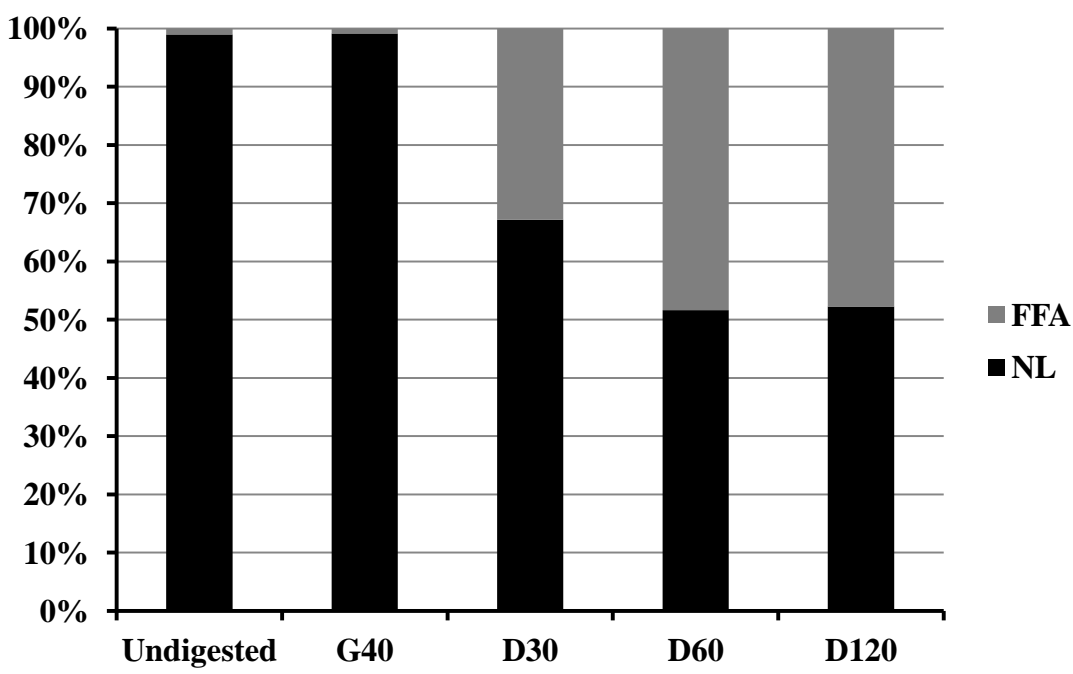

Figure 2. Proportion (\%) of neutral lipid and free fatty acid during the ex vivo digestion of Red Chittagong Cattle milk. G40, gastric digestion at $\mathrm{pH} 2.5$ for $20 \mathrm{~min}$; D30, D60, and D120, duodenal digestion for 30, 60, and 120 min, respectively at pH 7.0. Undigested and D120 are from duplicate data where others are from triplicate data.

samples were $0.10,0.11,5.50,2.10$, and 6.77 , respectively (for Figure 2). The average lipolysis (\%) of short chain fatty acids (C6:0-C8:0), medium chain fatty acids (C10:0-C16:0) and long chain fatty acids $(\geq \mathrm{C} 17: 0)$ was $52.0,33.3$, and 46.5 , respectively. This is in agreement with the lipase preferred positions; $s n-1$ and $s n-3$, where short chain fatty acids are more abundant followed by long chain and medium chain fatty acids (Angers et al., 1998; Blasi et al., 2008; Maansson, 2008). The unsaturated fatty acids, C14:1 $\mathrm{n}-5$, C16:1 n-7, and C18:1 n-9 showed almost similar lipolysis, ranging from $31.9 \%$ to $33.7 \%$ though their presence at lipase preferred positions of the triacylglycerol is different (Blasi et al., 2008) and mainly depends on the size of the triacylglycerol (Angers et al., 1998). The lipolysis of total saturated fatty acids and total unsaturated fatty acids showed little variation, $2.3 \%$ more in total saturated fatty acids. This is in contrary to the results of cow's milk (Devle et al., 2014), however, Islam et al. (2014; unpublished data) reported more lipolysis in total saturated fatty acids than the total unsaturated fatty acids in buffalo milk. According to Blasi et al. (2008) "saturated fatty acids were prevalently esterified in sn-3 position, while monounsaturated fatty acids in $s n-2$ position, with some exceptions". The stereospecific distribution of the fatty acids in the milk fat triacylglycerol comes out with considerable variability (Parodi, 1979; Angers et al., 1998; Blasi et al., 2008; Maansson et al., 2008).

\section{CONCLUSION}

In full fat milk from Red Chittagong Cattle, all the $\alpha_{\mathrm{s}}$ caseins were digested after 40 min of gastric digestion. However, some $\beta$-lactoglobulin was still intact after 120 min of duodenal digestion. The $\beta$-casein was degraded more extensively and contributed to the highest number of peptides. All the peptides identified from the different proteins were rich in proline along with other hydrophobic amino acids like alanine, leucine, isoleucine, valine, phenylalanie, methionine and tryptophan.

The milk fat showed $48 \%$ lipolysis. Short chain fatty acids showed higher lipolysis than the medium and long chain fatty acids and so were the total saturated fatty acids compared to the total unsaturated fatty acids. The Red Chittagong Cattle milk from Bangladesh showed a similar digestion pattern to Nordic cow's milk (Norwegian Red Cattle).

\section{REFERENCES}

Abd El-Salam, M. H. and S. El-Shibiny. 2011. A comprehensive review on the composition and properties of buffalo milk. Dairy Sci. Technol. 91:663-699.

Almaas, H., A.-L. Cases, T. G. Devold, H. Holm, T. Langsrud, L. Aabakken, T. Aadnoey, and G. E. Vegarud. 2006. In vitro digestion of bovine and caprine milk by human gastric and duodenal enzymes. Int. Dairy J. 16:961-968.

Almaas, H., E. Eriksen, C. Sekse, I. Comi, R. Flengsrud, H. Holm, E. Jensen, M. Jacobsen, T. Langsrud, and G. E. Vegarud. 2011. Antibacterial peptides derived from caprine whey proteins, by digestion with human gastrointestinal juice. Br. J. Nutr. 106:896-905

Angers, P., E. Tousignant, A. Boudreau, and J. Arul. 1998. Regiospecific analysis of fractions of bovine milk fat triacylglycerols with the same partition number. Lipids 33:1195-1201.

Armand, M. 2007. Lipases and lipolysis in the human digestive tract: where do we stand? Curr. Opin. Clin. Nutr. Metab. Care. 10:156-164. 
Blasi, F., D. Montesano, M. De Angelis, A. Maurizi, F. Ventura, L. Cossignani, M. S. Simonetti, and P. Damiani. 2008. Results of stereospecific analysis of triacylglycerol fraction from donkey, cow, ewe, goat and buffalo milk. J. Food Compost. Anal. 21:17.

Carriere, F., J. Barrowman, R. Verger, and R. Laugier. 1993. Secretion and contribution to lipolysis of gastric and pancreatic lipases during a test meal in humans. Gastroenterology 105:876-888.

Carriere, F., Y. Gargouri, H. Moreau, S. Ransac, E. Rogalska, and R. Verger. 1994. Gastric lipases: cellular, biochemical and kinetic aspects. In: Lipases: Their Structure, Biochemistry and Application (Eds. P. Woolley and S. B. Petersen). Cambridge University Press, New York, USA. pp. 181-205.

Devle, H., E. K. Ulleberg, C. F. Naess-Andresen, E.-O. Rukke, G. E. Vegarud, and D. Ekeberg. 2014. Reciprocal interacting effects of proteins and lipids during ex vivo digestion of bovine milk. Int. Dairy J. 36:6-13.

Furlund, C. B., E. K. Ulleberg, T. G. Devold, R. Flengsrud, M. Jacobsen, C. Sekse, H. Holm, and G. E. Vegarud 2013. Identification of lactoferrin peptides generated by digestion with human gastrointestinal enzymes. J. Dairy Sci. 96:75-88.

Gallier, S., A. Ye, and H. Singh. 2012. Structural changes of bovine milk fat globules during in vitro digestion. J. Dairy Sci. 95:3579-3592.

Gallier, S., J. Cui, T. D. Olson, S. M. Rutherfurd, A. Ye, P. J. Moughan, and H. Singh. 2013. In vivo digestion of bovine milk fat globules: Effect of processing and interfacial structural changes. I. Gastric digestion. Food Chem. 141:32733281.

Gass, J., H. Vora, A. F. Hofmann, G. M. Gray, and C. Khosla. 2007. Enhancement of dietary protein digestion by conjugated bile acids. Gastroenterology 133:16-23.

Haug, A., A. T. Hostmark, and O. M. Harstad. 2007. Bovine milk in human nutrition-a review. Lipids Health Dis. 6:25.

Hur, S. J., B. O. Lim, E. A. Decker, and D. J. McClements. 2011. In vitro human digestion models for food applications. Food Chem. 125:1-12.

Inglingstad, R. A., T. G. Devold, E. K. Eriksen, H. Holm, M. Jacobsen, K. H. Liland, E. O. Rukke, and G. E. Vegarud. 2010 Comparison of the digestion of caseins and whey proteins in equine, bovine, caprine and human milks by human gastrointestinal enzymes. Dairy Sci. Technol. 90:549-563.

Islam, M. A., M. K. Alam, M. N. Islam, M. A. S. Khan, D. Ekeberg, E. O. Rukke, and G. E. Vegarud. 2014a. Principal milk components in buffalo, holstein cross, indigenous cattle and Red Chittagong Cattle from Bangladesh. Asian Australas. J. Anim. Sci. 27:886-897.
Islam, M. A., D. Ekeberg, E. O. Rukke, and G. E. Vegarud. 2014b. Ex vivo digestion of omega-3 enriched buffalo skimmed milk. J. Func. Foods. (In press). doi: 10.1016/j.jff.2014.08.016.

Jensen, R. G. 2002. The composition of bovine milk lipids: January 1995 to December 2000. J. Dairy Sci. 85:295-350.

Kopf-Bolanz, K. A., F. Schwander, M. Gijs, G. Vergeres, R. Portmann, and L. Egger. 2012. Validation of an in vitro digestive system for studying macronutrient decomposition in humans. J. Nutr. 142:245-250.

Maansson, H. L. 2008. Fatty acids in bovine milk fat. Food Nutr. Res. 10.3402/fnr.v52i0.1821.

Medhammar, E., R. Wijesinha-Bettoni, B. Stadlmayr, E. Nilsson, U. R. Charrondiere, and B. Burlingame. 2012. Composition of milk from minor dairy animals and buffalo breeds: a biodiversity perspective. J. Sci. Food Agric. 92:445-474.

Miled, N., S. Canaan, L. Dupuis, A. Roussel, M. Riviere, F. Carriere, A. de Caro, C. Cambillau, and R. Verger. 2000. Digestive lipases: From three-dimensional structure to physiology. Biochimie 82:973-986.

Miranda, G., M.-F. Mahe, C. Leroux, and P. Martin. 2004. Proteomic tools to characterize the protein fraction of Equidae milk. Proteomics 4:2496-2509.

Mu, H. and C.-E. Hoy. 2004. The digestion of dietary triacylglycerols. Prog. Lipid Res. 43:105-133.

Pafumi, Y., D. Lairon, P. L. de la Porte, C. Juhel, J. Storch, M. Hamosh, and M. Armand. 2002. Mechanisms of Inhibition of Triacylglycerol Hydrolysis by Human Gastric Lipase. J. Biol. Chem. 277:28070-28079.

Parodi, P. W. 1979. Stereospecific distribution of fatty acids in bovine milk fat triglycerides. J. Dairy Res. 46:75-81.

Rogalska, E., S. Ransac, and R. Verger. 1990. Stereoselectivity of lipases. II. Stereoselective hydrolysis of triglycerides by gastric and pancreatic lipases. J. Biol. Chem. 265:20271-20276.

Tidona, F., A. Criscione, T. G. Devold, S. Bordonaro, D. Marletta, and G. E.Vegarud. 2014. Protein composition and micelle size of donkey milk with different protein patterns: Effects on digestibility. Int. Dairy J. 35:57-62.

Ulleberg, E. K. 2011. In vitro Digestion of Caprine Whey Proteins by Human Gastrointestinal Juices: Effect of Whey Hydrolysates and Peptides on In Vitro Cell Responses. PhD thesis, Norwegian University of Life Sciences, Aas, Norway.

Ulleberg, E. K., I. Comi, H. Holm, E. B. Herud, M. Jacobsen, and G. E. Vegarud. 2011. Human gastrointestinal juices intended for use in in vitro digestion models. Food Dig. 2:52-61.

Ye, A., J. Cui, and H. Singh. 2011. Proteolysis of milk fat globule membrane proteins during in vitro gastric digestion of milk. J. Dairy Sci. 94:2762-2770. 